\title{
TOWARDS A NEW PERSPECTIVE OF PROJECT EVALUATION: AN ISLAMIC OUTLOOK WITH SPECIAL EMPHASIS ON DISCOUNTING PROBLEM
}

\author{
Masyhudi Muqorobin
}

\begin{abstract}
Abstrak
Kontroversi dalam pandangan Islam tentang evaluasi proyek berkisar pada isu diskonting yang terkait dengan pengharaman suku bunga. Tidak banyak literature yang memfokuskan pada persoalan tersebut, sehingga pertanyaan mendasar yang terkait dengannya juga belum terjawab secara memuaskan. Dengan demikian, kebutuhan akan karya khususnya dengan perspektif Islam dalam kaitannya dengan evaluasi proyek amatlah mendesak. Selain masalah diskonting, isu lain yang berhubungan erat adalah analisa keuntungan dan biaya social dan metodologi evaluasi proyek yang masih langka dalam khazanah pemikiran ekonomi Islam, khasnya di Indonesia.

Dengan melakukan survey pada sejumlah karya ekonom Muslim yang terfokus pada permasalahan tersebut, tulisan ini menghasilkan temuan utama tentang kesesatan pendekatan Fisher mengenai preferensi waktu. Preferensi waktu dalam pandangan Islam bukanlah merupakan sebuah fenomena konsumsi sebagaimana pendekatan Fisherian, ia lebih merupakan sebuah fenomena produksi atau investasi. Ajaran nilai yang penting dalam Islam memberikan tekanan pada karya yang dilakukan oleh seorang Muslim, sementara untuk memiliki karya, diperlukanlah konsumsi. Dengan demikian, konsumsi hanyalah satu konsekwensi dari sebuah karya. Oleh karenanya evaluasi proyek dalam pandangan Islam memerlukan justifikasi metodologi yang diturunkan dari nilai-nilai Islam yang dinamis.
\end{abstract}

JEL Classification: $E-21, D-91, O-22$ and Z-12

Keywords: discounting rate, interest, project evaluation, rate of return, time preference

\section{INTRODUCTION}

Investment decision is a significant stage of project cycle determining whether or not a project can be undertaken, after evaluation of its feasibility from financial standpoint. It is thought to have been rooted from the great work of Irving Fisher in 1930s, The Theory of Interest (Hishliefer, 1965a). Project evaluation as a tool of analysis to determine the feasibility of a project is a relatively new branch of applied economics stemming from neoclassical Fisherian analysis, and invigorated by Keynesian writings. In the upcoming Islamic economics the subject is to be paid no less attention, though it remains largely unattended.
The controversy arises in Islamic viewpoint around the issue of discounting, due to candid prohibition of interest (riba). This paper analyzes project evaluation from such an Islamic view, with a special emphasis on discounting problem.

\section{SCOPE OF THE ANALYSIS}

The problem of time-related discounting encompasses four issues: 1) its existence in relation to time preference concept, 2) substitution of the role of interest rate by profit rate, 3) criteria selection for investment decision under the Shari'ah, and 4) efforts on investment model. Due to 
limitations, only the first two deserve sufficient attention, however.

On the other hand, some attempts on social cost-benefit analysis (SCBA) as required analysis for the feasibility of the project rest on elaboration of social welfare concept to which priority has been given over individual interest. Methodology of project evaluation still lacks attention, too. There are not many significant contributions in Islamic economics literature on the subject. Introducing Islamic alternative as advanced in a more general approach by Choudhury and Naqvi, as discussed below, is likely to have started enlightening scientific and academic inquiries in such an important area, where the present work seeks to make its humble contribution. Figure 1 depicts the sketch of methodology of the study in investigating the relevant Islamic economics literature on project evaluation.

Figure 1

Methodology for the study of project evaluation

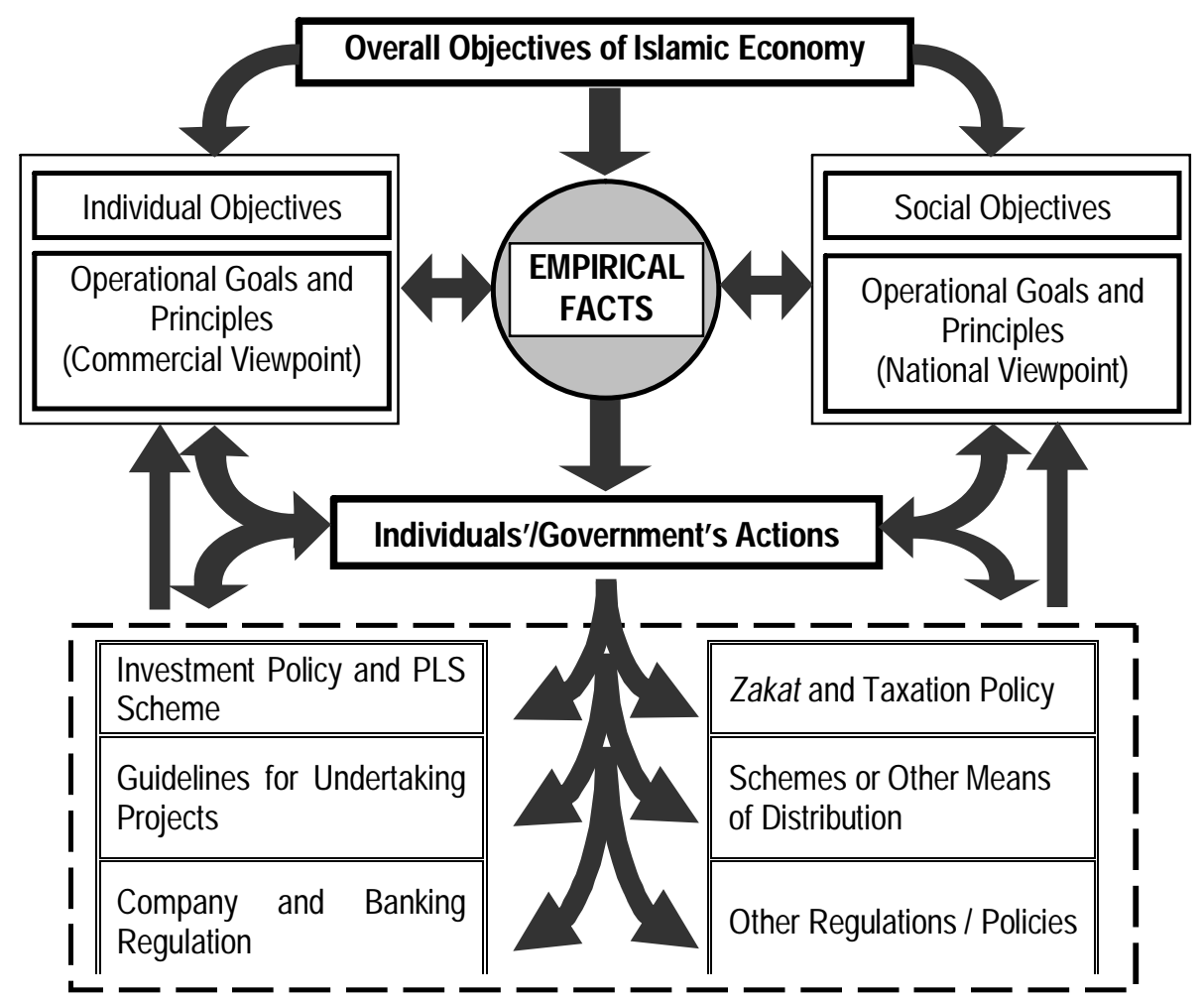




\section{CONVENTIONAL FRAMEWORK OF PROJECT EVALUATION}

Interest constitutes basis for determining criteria for an admissible investment project from the financial standpoint. Further determination of social discount rate in CBA to some extent has also relied on the existence of interest rate as associated with the positive time preference (UNIDOIDCAS, 1982). Interest as a "price" can be defined, following Fisher (1930), as "the per cent of premium paid on money (or wheat or any other sort of goods) at one date in terms of money to be in hand one year later." In general, interest rate determines the rate of investment relative to the gross national income and thereby the rate of economic growth. The lower the interest rates the higher the level of investment and thus the rate of economic growth. Accordingly, the investible resources of the project are influenced by the rate of interest.

The above proposition had been envisaged in a number of writings in the early years of the century, by Marshall, BohmBawerk, Walras, Knight, Wicksell, Fisher, etc. (Lutz, 1967). Fisher admits that inter-

Figure 2

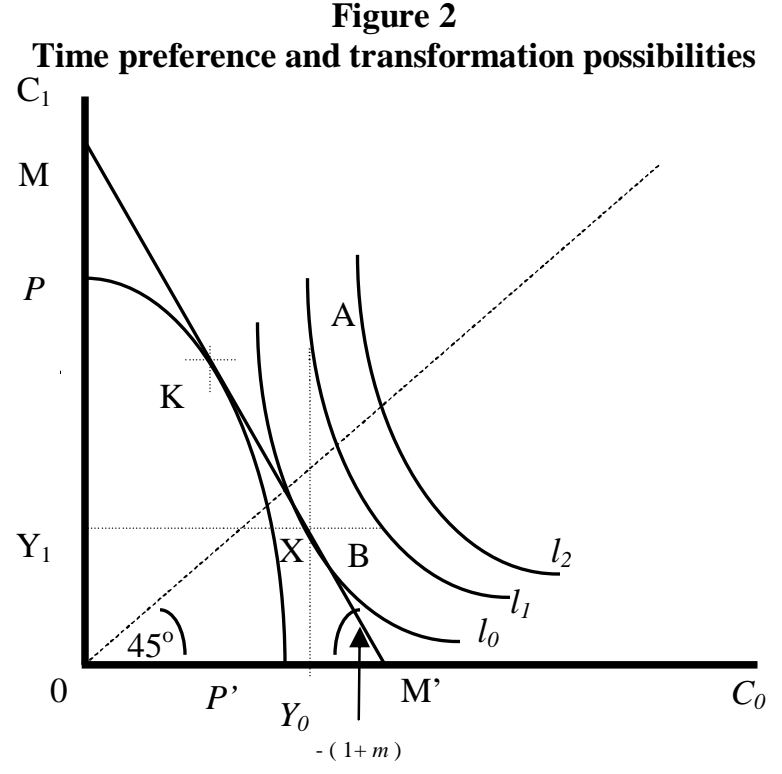

etc. (Lutz est's role is hardly separable from the involvement of time dimension to evolve discounting concept. Suppose "the value of dinner about to be eaten involves no time of waiting and so no discount or interest," meaning inversely that the price of any good or service (or in a generalised sense, asset) that involves time for waiting should be discounted, or in other words, "interest should be accounted for." This is the very beginning of the process of determining the rate of interest.

The process begins with the difference between interests of two assets, matched exactly by the expected change in their relative prices, to form an interest parity formula (Niehans, 1990):

$$
\frac{1+j}{1+l}=1+a
$$

where $i$ and $j$ are the interest parity rates on individual assets 1 and 2 respectively, showing that each asset has its own interest rate related to its future price expectation, and $a$ is expected appreciation of asset 1 relative to asset 2 .

IQTISAD Journal of Islamic Economics, Vol. 4, No. 1, Muharram 1424 H/March 2003 
Fisher accomplishes the model by making use of time preference (consumption) and production possibilities, and their relationship with income in terms of general equilibrium framework. Figure 2 provides two basic foundations of neoclassical theory that are blamed for the originating causes of the existence of interest rate: first, time preference that defines the objectives of individuals' intertemporal preferences; and $s e$ cond, production function that defines the constraint, transformation possibilities, from the available individual's income.

Consider a two-period case, where indifference curves describe present and future individual consumption. Its slope illustrating the rate of exchange between units of present consumption, $C_{0}$, and that of the future, $C_{1}$, can be developed in the same way as definition (1):

$$
\frac{d c_{l}}{d c_{0}}=-(1+i)
$$

The slope also reflects the marginal rate of time preference (MRTP) consumption, which is influenced by two factors: available amounts of present and future consumption, and individual income. If an expected future income of an individual is higher than current income, at above 45 degree line (suppose at point $\mathrm{A}$ ), he will tend to give up a larger amount of $C_{l}$ for a given increment in $C_{0}$, than that one at B under the 45 degree line. The $45^{\circ}$ line through the origin illustrates the equality amount of present and future consumption. Along the line, the individual still gives up more than one unit of $C_{l}$ for an additional unit of $C_{0}$, as indicated by the asymmetrical indifference curves in the figure. This exists because people are impatient and, at the same time, want to get opportunities for investment. ${ }^{1}$

\footnotetext{
1 The belief in positive time preference always exists in an empirical fact is also seen from the title of Fisher's book itself: Theory of interest (The theory of
}

On the other hand, MM' is the only income constraint that reflects the financial opportunities facing the individual, with the slope of, say to avoid confusion from the MRTP slope, $-(1+m)$. If the present individual's income is entirely spent for $C_{0}$, the situation is represented by point $\mathrm{M}^{\prime}=\mathrm{Y} 0+$ $Y_{l} /(1+m)$, he avoids using his income for financial opportunities in the future. Conversely, $\mathrm{M}=Y_{1}+Y_{0}(1+m)$, represents another extreme for putting all income for future financial opportunities and not to consume today. Along the line MM', the income (or budget) constraint becomes $C_{0}+C_{l} /(1+$ $m)=Y_{0}+Y_{1} /(1+m)$, where financial opportunities may be exchanged, so as to form a "market line".

Financial opportunities also provide production possibility frontiers, one of which is, $P P$ ', illustrated as "another blade of a scissors." $\mathrm{K}$ represents an optimum choice of a combined set of production possibilities, shown by the tangential of the market line to the frontier, so that the marginal rate of transformation (MRT) of $Y_{0}$ into $Y_{I}$ can be given by:

$$
\frac{d y_{1}}{d y_{0}}=-(1+r)
$$

If the optimum levels of both, the utilities represented by indifference curves and the production possibilities, meet at one point in this line, where the production frontier is tangential to the indifference curve, there will be no trading. So, his equilibrium condition is attained at such a point. Otherwise, there will be alternatives for mechanism enduring the "lending" and "borrowing" process reflected in the movement along the market line. Given the income in the current period, an individual who wants to attain an

interest as determined by impatience to spend and opportunity to invest.

2 This market line is steeper than 45 degree line as "future income decreases faster than the present income increases," when interest rate exists. See ibid, p. 236 . 
optimum productive level at $\mathrm{K}$, can consume money amount of $C_{0}-Y_{0}$ as depicted in at his optimum utility by borrowing the

Figure 3.

Figure 3

A lending-borrowing mechanism

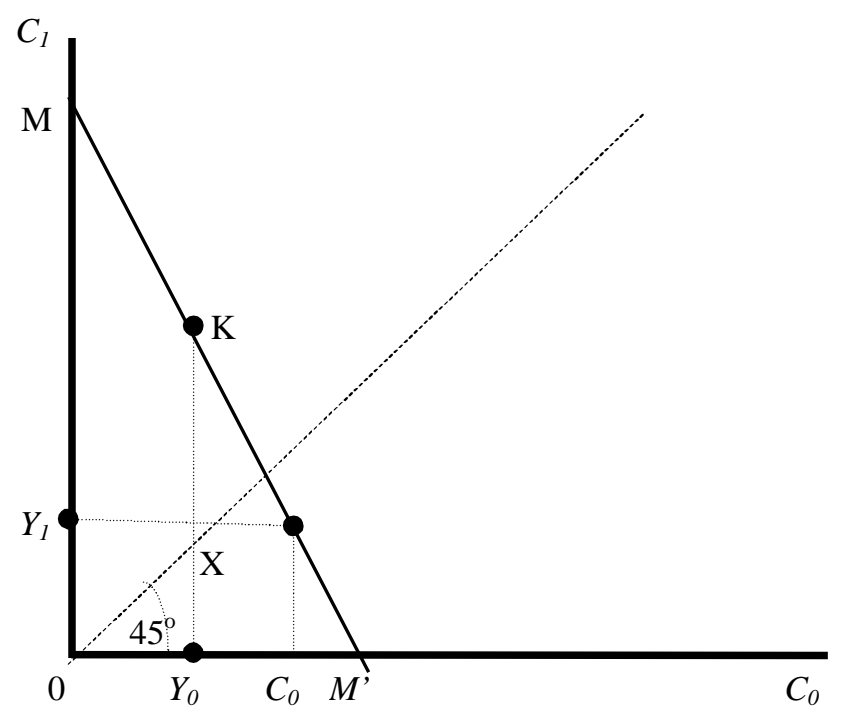

Figure 4

Saving and investment equilibrium

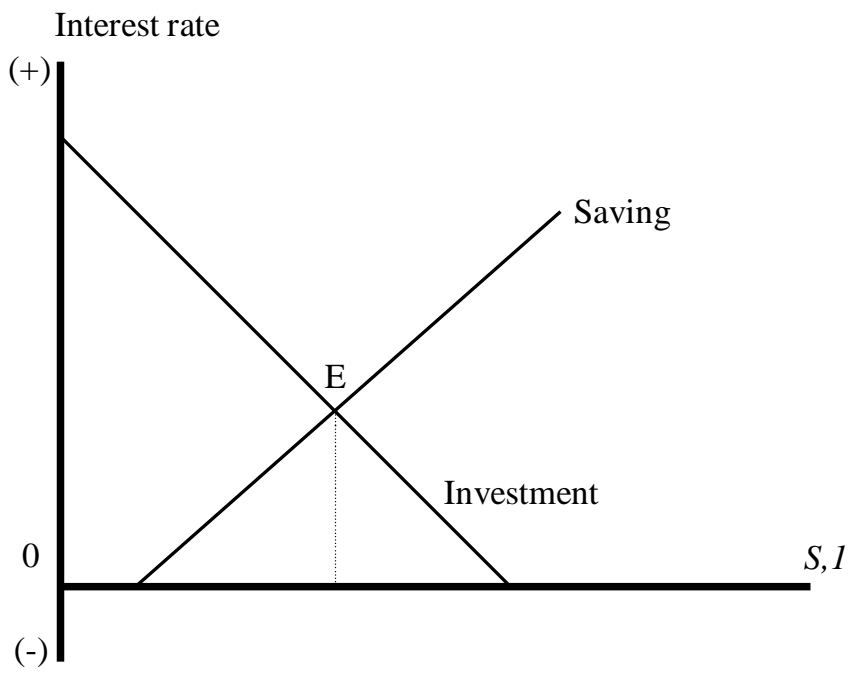


There are two potential reasons for why positive interest rate is said to exist: first, bias in favour of the future consumption available through the attainment of certain level of production, shown by asymmetric production possibility frontiers; and $s e$ cond positive bias of individual's time preference (Dougherty, 1980). The establishment of equilibrium with positive time preference is also influenced by two factors: subjective preference affected from tastes and expectation of the consumers and technology that influences the production possibilities.

With the help of Figure 3, we can derive a demand for and supply of loanable funds, for each individual as a function of the rate of interest. It should be thought that intertemporal efficiency conditions are stipulated in a general equilibrium, which is simultaneously determined by all agents. Accordingly, individual consumptioninvestment decisions can be undertaken, given the information of interest rate. On the other hand, interest rate is known after the aggregate consumption-investment has been made by occupying market mechanism of loanable funds. The Walrasian auctioneer is hence used to determine the rate of interest. In order to satisfy the Pareto Optimality in general equilibrium, the aggregate lending must equal the aggregate borrowing. Thus, the equality of MRTP or $i$ (definition 2), MRT or $r$ (definition 3), and also interest rate reflected then in the market $(m)$, to all individuals is attainable. Figure 4, derived from Figure 3 by reformulating time preference consumption in terms of savinginvestment relationship, depicts the market mechanism of loanable-funds illustrating the equality of saving and investment.

Above all, it should be thought that the approach could optimally work if several assumptions are satisfied. As believed in neoclassical tradition, perfect competition is considered the main assumption, which sets the condition of perfect foresight, so that the lack of uncertainty is also held. Continuity and convexity are also held for both the indifference curves and possibility frontiers, so as to produce a unique optimum solution for each schedule at the same market line.

The approach in general is under fire particularly regarding the assumption of perfect foresight by which each individual and obviously also each firm - knows all future prices, including interest rate obtained in the economy, or knows all individuals' preference orderings and firms production possibilities. Temptation of relaxing this assumption, following Dougherty, takes into three different forms, one of which is said to simply assert that perfect foresight assumption is convenient for exposition of the Fisherian theory, but misleading impression in practice concerning both the information required and its collection difficulty. Keynes admits the importance of uncertainty, and it may lead to violating the fulfilment of expectation. However, he supposes that the long run model is unbiased.

There are two interesting features relating to invigorating the neoclassical position by the Keynesian approach: (1) time preference and propensity to consume, and (2) loanable-funds theory and liquidity preference theory. Propensity to consume determines the use of individual's income for current consumption and for reserving in some form of command over future consumption. In general, this is similar as time preference consumption concept as Keynes (General Theory) himself confesses. The second, equality between loanable-funds and liquidity preference theories of interest is, so far, open to controversy, in particular among neoclassical and Keynesian economists. ${ }^{3}$

The investment theories of saving can be observed differently. Neoclassical

\footnotetext{
3 For further detailed study on this dispute, refer to for instance G.C. Harcourt (editor), The microfoundations of macroeconomics, International Economic Association, Macmillan, London, 1977.
} 
economists envisage the significance of individual's role in the market to create equilibrium. Since the society is composed by individuals and each individual will optimize his attainment, therefore the optimum level of attainment in the society reflected in the equilibrium can be achieved. Determination of the equilibrium "price" that is equilibrium rate of interest may be achieved with individuals' role through the market mechanism. In contrast, Keynes, stressing the role of entrepreneurs perceives the equality of saving and investment through the aggregates income and consumption, by equating income with the value of output resulting from entrepreneurs' efforts. He defines the equality of saving and investment as:

$Y=Q=C+I$

$S=Y-C$

Therefore,

$S=I$

where in the aggregate terms, $Y$ and $Q$ denote income and the value of output respectively, $C$ is consumption, $I$ represents investment, and $S$ stands for saving.

Neoclassical tradition perceives the need for (and also supply of) saving, as a function of interest rate (Figure 4) even as most economists of this tradition including Fisher himself are aware of the influence of income and substitution effects on the amount of borrowing. Thus, Keynes suggests, savings may not be completely determined by the rate of interest. ${ }^{4}$ He views that the "propensity to save" is another expression of "propensity to consume", which is a function of income. Therefore his conclusion that full-equilibrium level of savings, without the role of interest, will equate the requirements for investment can be consid-

\footnotetext{
${ }^{4}$ Contrasted with the above, Dougherty's (1980) suggests that Fisher himself did not believe that savings would necessarily be stimulated by an increase in the interest rate.
}

ered as invigoration of the neoclassical approach.

\section{ISLAMIC SYNTHESIS BASED ON THE LITERATURE SURVEY \\ Prohibition of Riba: Possible Differences?}

On the philosophical ground, it is unanimously acceptable that riba is prohibited. However, Choudhury (1986) observes, different interpretation to what extent riba equals the modern economic term "interest" still happens. Mannan (1975), according to Choudhury, views that some forms of "interest" is inevitable as it is a reasonable excess, thus does not meet the meaning of prohibited riba, to which the word "usury" is closer, and "the difference between riba and interest is the one of degree not of kind." However, on another study, Mannan (1992) rules out the role of interest as a cost of production from the Islamic socio-economic set up. This view is also supported by Haneef (1415/1995): "The Islamic economic system will also be free of interest, which is categorized by Mannan (1980: 221-35) and the majority of jurists and Islamic economists as riba." Therefore, categorization of interest as riba is unanimously agreed and even unchallenged.

Another objection comes from Naqvi (1981a, 1981b, 1983, 1994), concerning interest abolition as a consequence of its candid prohibition, in his "transition period." It is inadequate to abolish interest, particularly using administrative fiat during the period. This also appears in his joint effort with Qadir (1981), and with others in

\footnotetext{
5 He defines the "transition period" as "the transition from the present un-Islamic economic system to a complete Islamic economic system" as the "second best" choice before arriving at the "first best" or the complete economic system (see Naqvi, 1981a, p.33). The period "of translating the Divine message within the crucible of real-life institutions" (Naqvi, 1992, p. 8).
} 
An Agenda for Islamic Economic Reform. ${ }^{6}$ However, if all conditions for a "complete" Islamic economic system are satisfied, he maintains, prohibition of riba implies the existence of "exploitation-free" economy, not only "interest-free" economy, as it accordingly implies elimination of the entire capitalistic system. The logic is that abolition of interest is necessary condition for such a system, but not sufficient (Naqvi, 1981a: 110). He further admits, in the context of capitalism as adhered by the majority of Muslim countries, positive interest rate is of its properties and thus satisfies the criterion of equilibrium. Hence, as capitalism bases its operation on limited liability to risk, limited knowledge about large-scale enterprise logically implies only a limited risk (1981a: 111-112). To provide arguments, he develops a model based on the assumption that positive time-preference is given in the society as a decreasing function of time (Naqvi 1981b and 1983, Naqvi and Qadir 1981). It is "reflecting the essentially myopic nature of individual's economic calculus" (1981a: 115), and should be acceptable in Islam (1994: 114).

\section{Abolition of Interest: Its Set Up in Islami- zation of the Economy}

In an Islamic economic reform, i.e. Islamization of the economy, Naqvi and his group advocate a gradual (Naqvi 1981a), dialogic or even a compromise process (Naqvi 1994). The purpose is to let the existing conventional economic system gradually dissolves and smoothly provides a chance for the Islamic reforms to take place, without any significant impact to the society.

\footnotetext{
6 An Agenda is a report of the Committee on Islamization of Pakistan Economy, appointed by the Government of Pakistan, having members: Naqvi, H.U. Beg, Rafiq Ahmed and Mian M. Nazeer. An Agenda was published by Pakistan Institute of Development Economic, Islamabad, 1989. See pp. 20-21.
}

\begin{abstract}
"The elements of the Islamic reforms must be looked at in relation to its "totality" - i.e. the 'fact' that Islam's is a complete socio-economic system....

The pace of the Islamization process must be slow enough to allow the existing economic system to change on abroad front and to maximise the flow of knowledge about how the Islamic system operates in practice."

(Page 10-11):
\end{abstract}

However, they suggest, such a reform requires a policy package, in which, among others a priority is given to a programme for Islamizing the institution of private property, where Muslims live under oppressive feudalistic system. Differently speaking, the issue here is not a mere prohibition of interest but by and large Islamization of Muslim economy.

By contrast, the majority of Muslim economists in project evaluation who advocate the interest abolition consider undertaking a segmental step of contribution towards the Islamization process, in which their participation is of great significance. A comparative feature of the above process from the starting point of interest abolition in project evaluation context is depicted in Figure 5. 
Figure 5.

Riba Prohibition Relating to Project Evaluation and Its Impact on the Process of Islamization of Economy

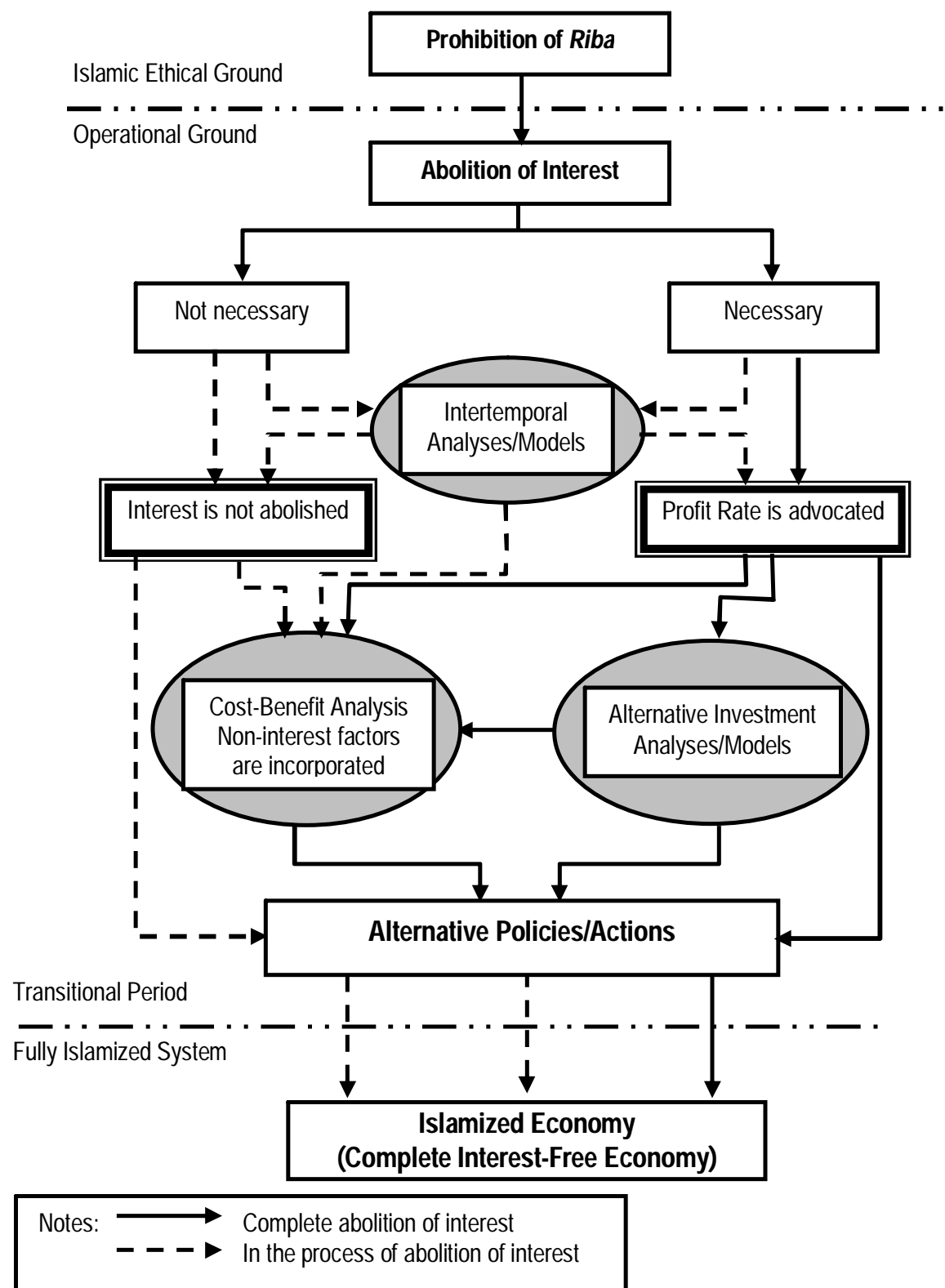


Haque and Mirakhor (1986) accentuate that the notion of the absolute prohibition of interest is clear. Thus, application of PLS system, as at least interpreted under mudharabah and musharakah schemes is plausible without resort to charging of interest. As there have been sufficient works on this notion, further discussion is thought unnecessary. However, theoretical elaboration is required to supply with a rigorous support for the study. For methodological purposes, the study again classifies the analyses into two categories, first, intertemporal or timepreference analysis/model, and second, nonintertemporal analysis/model.

\section{On the (Fault) Assumptions}

Islamic economic analyses, including those in the first category, as usually held in conventional economics, begin with a set of assumptions. In analyzing the first category, neoclassical assumption of perfect foresight or certainty plays a dominant role as explicated by Azhar (1992), Haque and Mirakhor (1986), and firmly defended by Naqvi in all his works under examination including his joint effort with Qadir (1981). Zarqa' (1982 and 1983), to the contrary, harshly criticises its use as unrealistic and even un-Islamic. The study holds the view that in developing such a model, this assumption is considered necessary at the initial level. Nevertheless, unlike Naqvi, we should also take into account the real world to make this assumption less stiff, so as to fit the model with the existing facts of the Muslim economy, or at least to compare between two states of situation (Haque and Mirakhor, 1986). This step was also elaborated more or less in conventional position, the previous chapter. It explains that in the "first best" economy, where this assumption is theoretically applicable, the equality of the market rate of interest, MRTP and MRT (or $m=i=r$ ) is warranted - though the fact tells otherwise, even in the US economy. The difficulty is that, since
Naqvi and his group maintain that this state of world remains unchanged, even in the Muslim society (because of adhering capitalistic economy), the abolition of interest and its substitution by profit is, to them, not reasonable. Under this assumption, it is not surprising; either interest-based fixed or interest-free variable rates of return serve the same answers to the problem.

Islam does not let perfect competition as conceived in mainstream position exists in the market, but maintains that a sound competition is encouraged so that prices can clear the market in an adequate way without anyone being exploited. Therefore, the state plays a key role in establishing the institution of hisbah ${ }^{7}$ to ensure socio-economic justice in the society so that exploitation will not materialise in the market.

Another mistake that they uphold, it looks, is the assumption that Muslims similar to their counterparts in a secular society - adhere the positive time preference, resulting the belief in positive rate of interest. The relationship of these two elements is, following Zarqa' (1982 and 1983), Kahf (1994), and Khan (1991 and 1995), not considered necessary. Positive interest rate may happen even when negative or zero time preference in consumption is held. Regardless of their relationship, the study finds that the assumption is fault in itself. It contravenes the Islamic precepts that one should consider and think of their own future and future generation, so as not to exhaustedly consume their current income (or in general resources) leaving nothing for their future, but rather to sacrifice for them.

\footnotetext{
There are large numbers of works on Hisbah, the well-known one was written by the great scholar Ibn Taymiyyah (al-Hisbah fi al-Islam). It has three functions one of which is to regulate market. for short elaboration, see for instance Muhammad Akram Khan, The role of government in the economy, AJISS, vol. 14, No. 2, Summer 1997, pp. 155171.
} 
Most importantly, it is hard to find internal consistency in Naqvi's (1981a and 1994) suggestion in this context, as he in contrast also suggests the need for sacrifices on present generation for the sake of posterity. The position of the study, on the other hand, opposing Khan's (1991 and 1995) notion that Islam is nothing against positive time preference in consumption, concludes that Islam suggests the contrary. Zarqa' (1983) supplies arguments against positive bias of time preference in consumption from microeconomics perspective and macro as well; nevertheless, he does not clearly advocate the negative bias. Therefore, it is of the task of the study, occupying such arguments, to explicate the validity of negative time preference in consumption in Islamic economics, based on the assumption that most of the Muslims are obedient to the Islamic precepts.

To conclude this section, it should be held that resources (that can be defined for technical reason as either consumption or production goods) are created by (and belong to) Allah, and then He hands over these resources to all mankind for their use. ${ }^{8}$ Therefore, all goods are by definition "public goods". It does not necessarily imply similarity between Islam and socialism, that private ownership is not acceptable. Private ownership is possible to function provided only using the lawful means. Two consequences may be derived from this conclusion:

1. It is unanimously acceptable, even in conventional economics, that (market) interest rate is rejected (or at least inappropriate) to reflect the time preference rate or rate of discount in project evaluation.

\footnotetext{
al-Qur'an, surah al-Baqarah 2:29. This verse is nicely elaborated through the concept of amanah in Hasan's "Distributional equity in Islam" and its comments by Shafey (1986).
}

2. Welfare of future generation should be considered, not only at the level of government, but also individual's decision. The decision for the government is taken either through democratic process as Marglin (1965) observes, or administrative decision as appears in, for instance, Feldstein (1964).

\section{TIME DIMENSION AND DISCOUNT-} ING ISSUE.

\section{Islamic Perspective on Time Dimension}

Attainment of the falah (success) as the ultimate objective of any Islamic economy carries the concept of timepreference, current and future socioeconomic setting. This also tells us that future dimension illustrated by the ultimate falah in the hereafter, should be more valuable than that one in the world. Appreciation of this matter will presumably govern the Muslim to prepare for their future lives better. The Qur'an clearly states the Islamic appreciation of time. Allah says:

$\mathrm{O}$, ye who believe! Fear Allah, and let every soul look to what (provision) he has sent forth for the morrow. Yea, fear Allah: for Allah is wellacquainted with (all) that ye do. (alQur'an, surah al- Hashr 59:18)

By the time, verily man is in loss, except those have Faith, and do righteous deeds, and (join together) in the mutual enjoining of truth, and of patience and constancy. (alQur'an, surah al-'Asr 103:1-4)

When success is defined in terms of operational objectives, consequently, time dimension has to be defined, too, in more operational levels. Considering the importance of time dimension, Islam provides the notion of deferment in transaction. In principle, there are two kinds of deferment in Islamic transaction as mentioned in Kahf (1994), and Khan (1991 and 1995): bay' 
muajjal or nasi'a for deferment in price, and bay salam for item deferment (Sa'adillah, 1415/1994). An undertaking of a project can be defined to follow both the types of transaction. Khan views the deferment as recognition of time value of money as there is time element involves in the process of exchange. Hence, not only time preference should be considered but also supplydemand mechanism. Accordingly, it should be time preference or intertemporal factor that needs examination here. Choudhury (1986 and 1992) suggests derivation of intertemporal consumption-investment menu from the attainment of the falah in the hereafter, as principles of maximization of the total felicity attainment. Together with the principles of work and productivity, among others, the principle of maximizing total felicity yields Islamic time-preference in consumption and investment.

Kahf (1994) may be true in revisiting Khan's (1991) view that time value of money is not a purely consumption phenomenon, it is rather of an investment. Kahf's suggestion seems to fit for the Islamic precepts. The purpose of the human creation is nothing but for the obedience to Allah, ${ }^{9}$ the activity man can observe. Therefore, the principle of work and productivity or in other word entrepreneurship becomes the pivotal role, which a Muslim has no other choice.

"Life is for struggle" man's achievement in fulfilling his obligation and service to Allah. Work or activity (or to be more specific investment or production) is given priority over consumption, as in this sense that consumption constitutes a means and production is an ends. Combination of both may lead to attaining the optimum obedience to Allah, and one can survive to maximize his service to Allah. The

9 al-Qur'an, surah al Dzariyat 51:56

10 al-Qur'an, surah al-Balad 90:4. emphasis on production or investment side obtains philosophical bases as compared to consumption that deserves only "moderation" (not "maximization") of human commitment. It is therefore theoretically reasonable to find using this way the rate of profit as appropriate measure of investment criterion in an Islamic economy (Azhar 1992).

\section{Developing an Intertemporal Analysis: New Consideration?}

Having discussed the philosophical basis, and thus holding the assumption of selecting time preference from the investment viewpoint, we can develop a theoretical construct of intertemporal analysis. The study hence underlines Azhar's (1992) explicit statement that optimality conditions primarily pertain to saving and thus investment, which leads to optimality in intertemporal consumption, as the latter is dependant on the former. These conditions provide for an emergence of intertemporal consumption as a concomitant fact, in exactly the same way as neoclassical analysis treats the emergence of investment from intertemporal consumption.

The process begins with leaving aside the positive time preference in consumption, in favour of that of negative. The second step is to transform from consumption to production perspectives through a saving-investment mechanism. We can thus reformulate positive bias in "time preference" in terms of investment where positive rate of discount may still exist. In short, we resort to finding justification from consumer theory. Figure 6, following the same notation as in Figure 2, depicts the negative bias in time preference, shown by the asymmetric indifference curves in favour of future consumption. It follows the logic for the existence of positive time preference illustrated in the previous chapter. 
Figure 6

Negative time preference in consumption

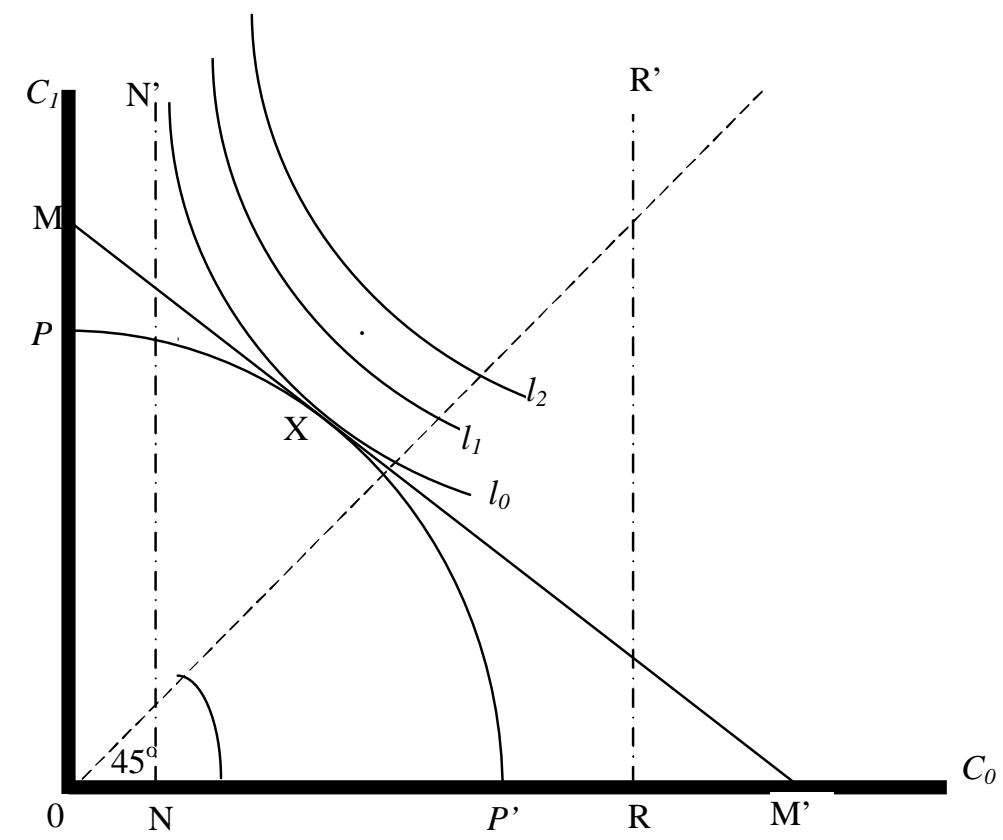

Figure 7

Positive bias in intertemporal production possibilities

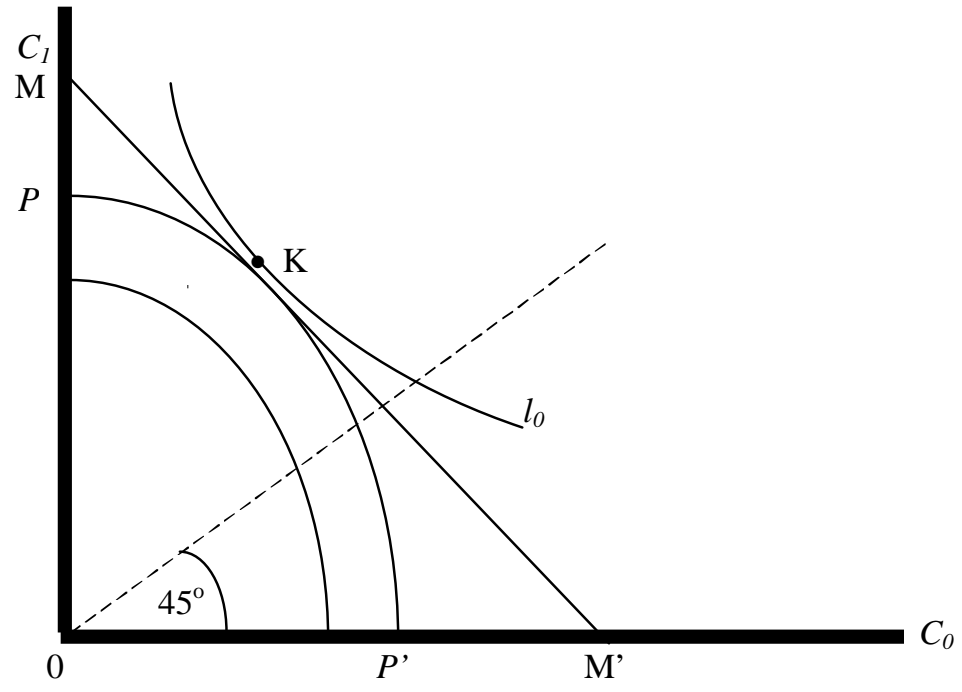


Supposing a symmetric production possibility frontier, the optimal point (X) lies at the above $45^{\circ}$ ray from the origin, and there exists the negative rate of time preference. The study considers the rationality axiom of lexicographic preferences (ordering) in conventional framework, as also suggested by Zaman (1992), reflecting the fulfilment of five basic necessities as mentioned previously, represented by NN' line. Moreover, Zaman's axiom of satiation of basic needs is borrowed, and expanded to accommodate all types of consumption in general, to be applied within Prodigality frontier, RR', as discussed by Zarqa' (1992), or under Choudhury's (1986, and 1992), and Choudhury's and Abdul Malik's (1993) principle of la israf. This can be so under time preference concept derived from the principle of attaining the maximum falah as presumably being held on one hand, and holding both the physical and Islamic ethical constraints i.e. of avoiding extravagance ${ }^{11}$ to achieve efficiency on the other hand.

Anyone will obviously decide to consume first before saving decision is undertaken. However, it should be assumed that after fulfilment of basic necessities, a Muslim's income is sufficient to make him decides whether to put aside a fraction of it for saving or to entirely spend it on consumption. Therefore, the dharuriyyat (necessities) line (NN') is the minimum level after which he, as a Muslim, is faced with two choices: investment decision, and pursuing further consumption for hajjiyat (conveniences) and tahsiniyyat (refinements) approaching the maximum consumption level, the israf line (RR'). He should first think of its postponement in favour of future consumption or investment, for the reasons explained above.

Hence, the optimality conditions occur at $\mathrm{X}$, where the absolute value of the slope of an indifference curve $\left(d c_{1} / d c_{0}\right)$ as

\footnotetext{
11 al-Qur'an, surah al-Isra 17:27
}

defined in equation 2 is less than unity. At such a point, MRTP equals MRT (and as claimed in conventional analysis, equals interest rate, OM/OM'). So that MRTP is less than zero. $(1+i)<1, i<0$. It is seen that the positive interest rate constitutes something impossible to exist under such a condition. Even if possible, it is difficult to think as there is no rationale for discounting in such a situation as also held by Zarqa' (1983).

It should be thought that in Islam, the lexicographical ordering and satiation concepts (reflected in the fulfillment of basic necessities and prodigality frontier respectively) altogether inherently entail individual and social obligatory responsibility for the people and the government to sustain the needy, whose income is not sufficient to meet these basic necessities, including those who have no income, i.e. children and disabled. This responsibility is then explicated through the formation of future consumption that can be defined in terms of saving.

There will be two alternatives for the consumer, whether he wants this saving to be idle; or converts it into investment for production purposes. Both of these purposes have individual and social welfare enhancement roles too. The former i.e. idle saving exceeding the level of nisab (minimum level to allowable deduction) is subject to yearly $2.5 \%$ zakah rate, ${ }^{12}$ which individually purifies his saving, and increases his spiritual uplift and achievement of falah in the Hereafter. Hence, this saving will be gradually diminishing to a certain level every year. To prevent it from diminishing because of $z a$ $k a h$, he can thus take the latter position for

\footnotetext{
12 The rates of zakah(t) are, as already well known according to the traditions of the Prophet (pbuh), fixed $2.5 \%, 10 \%$ ('ushr), $20 \%$ (khums), etc.(See for instance Naqvi, 1994, p. 102). However, we take a normal rate for this kind of wealth as also taken by Bashir and Darrat (1991); Choudhury (1986, 1992); Choudhury and Abdul Malik (1992); Hallaq (1994); Khan, 1995; Sattar (1991).
} 
investment, from which he can get the returns. The social dimensions of this choice stem from the schemes under PLS system, in particular, where participation of workers is considered. A brief discussion on such social dimensions shall be in the next chapter.

The advocacy of using investment viewpoint necessitated in time preference analysis, however, does not necessarily means that analyses emphasizing on consumption lose their relevance, as both perspectives are inseparable. Consideration to time preference consumption function will serve a clear view in analyzing the societywide context, in order to incorporate redistribution of consumption of outputs of an investment (either private or public) through time. ${ }^{13}$ Naqvi (1981b and 1982), and Naqvi and Qadir (1981) modeling the capital theory, start their analysis from production function. Haque and Mirakhor (1986) use equation $3.4-3.6(Y=C+I ; S=Y-C=I)$ to define the utility in macro-consumption space in terms of investment with a certain rate of return. A positive investment time preference, or in our term MRT $(r)$ equating to positive rate of return, is possible to exist, resulting from positive bias in future production for the availability of future consumption.

However, since the significance of consumption time preference is merely considered as a concomitant fact, its optimal point $(\mathrm{X})$ always coincides with optimality condition yielded from an investment decision $(\mathrm{K})$ as illustrated in Figure 7.

Consequently, there is no lending-borrowing mechanism as happens in conventional analysis (compare to Figure 3 ). It is unanimously agreed that Islam does not allow such a mechanism. The figure depicts the "only possible" cause of the existence of positive rate of return stemming from positive bias in production possibilities, from

\footnotetext{
${ }^{13}$ See M. S. Feldstein (1964, p.369).
}

which profit rate comes to the existence. This positive bias in future production is reasonable due to factors, as mentioned previously. First, subjective preference affected from tastes and expectation of the consumers, which being consistent hence shall be defined as such that future consumption will serve higher quality as associated with the second. Secondly, technological changes, on which, as Haque and Mirakhor theoretically prove, entrepreneur's investment decision depends. There are some other factors, it is observed, which (should) influence such a bias:

1. Labours participation in PLS schemes increases their job responsibility, accordingly, ensures the quality enhancement of their products over time;

2. Research and development (established in a company) is an important factor in improving the product quality too; and

3. An increase in demand that calls for further expansion of the product, given the fact of high increase in population particularly in Muslim countries.

\section{The "Fallacy" of Fisherian Approach}

The finding does at the same time correct the "fallacy" (from Islamic viewpoint) of the Fisherian approach, which can be discerned from two features. First, Fisher's first stage (approximation) says that the income stream of an individual can be modified trough lending-borrowing mechanism. Islamically, it is completely considerable (but not encouraged) ${ }^{14}$ especially for consumption purposes, provided no interest bearing entails in the mechanism, as he otherwise necessitates as a consequence of the

\footnotetext{
14 The Prophet (pbuh) is reported to have said: "O Allah; I seek refuge in Thee from sin and from being in debt." Someone asked him: "How often does thou, O Messenger of Allah; seek refuge from being in debt?" He said: "When a man is in debt he speaks and tells lies and he promises and breaks the promise." (narrated by al-Bukhari). Quoted from M. A. Mannan, Understanding Islamic finance, p. 27.
} 
"fallacy" of his human impatience. Fisher is true that humankind by nature, as the Qur'an says, is hasty, ${ }^{15}$ impatient, and sometimes combined with fretful and niggardly. ${ }^{16}$ These characteristics in general belong to all mankind. However, Islam comes into the world to make use of human Free Will to get them emancipated from domination of such bad natures. Therefore, the assumption of the obedience of the Muslim following the Qur'anic teaching, rules out the assumption that Muslims and non-Muslims behave similarly, or in other words, that these characteristics are applied, too, to the Muslims "eternally" (especially in consumption), which is also clearly used in all Naqvi's works under consideration.

On the other hand, Islam provides PLS system for production purposes, though in the modern times Muslim economists have invariably considered several modes of financing that combine both (interest-free) lending-borrowing and PLS mechanisms, with the use of some Islamized conventional modes of financing. Second, in the second approximation, he suggests that modification of income stream is possible by ("buying and selling" the income to) investing, with interest rate as a "price". He equalizes the "intermediate rate of interest" and the "rate of return over cost" as a result of investment (Fisher, pp: 155-158), as explained in Table 1 (partially quoted from his Table 7, p.156).

For more convenience, occupying the interest parity formula (formula 3.1), we may obtain:

$$
\frac{1+j}{1+i}=1+a
$$

which can be reformulated to get:

$$
a=\frac{1+j}{1+i}-1=\frac{(1+j)-(1+i)}{1+i}=j
$$

where $(1+i)$ and $(1+j)$ representing an asset in two different points of time, say now

\footnotetext{
15 al-Qur'an, Surah Bani Israil (al-Isra) 17: 11.

16 al-Qur'an, Surah al-Ma'arij 70: 19-21.
}

and one year later. If the values of $i$ and $j$ are respectively 0 and $10 \%$, therefore, we can find that $a$ is $10 \%$ representing an "intermediate rate of interest". He immediately shifts to the concept of "rate of return over cost." The Table shows that there are two options (or investment opportunities) the farmer faces, say by the farming use; to produce $Q_{i}$, and second, forestry use; to produce $Q_{j}$. At the initial period (first year), he thinks of taking the second option with the cost of losing his opportunity to get the first option $\left(Q_{i}-Q_{0}=\right.$ $\$ 100)$. $Q_{0}$ represents the dollar amount to be reduced at the initial period, when he undertakes the investment project (equals zero). Fisher calculates the rate of return over cost, say $p$, as: ${ }^{17}$

$p=\frac{Q j-Q i}{Q i-Q 0}$

$P=\frac{210-100}{100}=10 \%$

Equations 7 and 8 are not really similar. The former talks about interest rate while the latter explains more on profit rate. It is seen that rate of return over cost at that particular time is appropriately considered as profit rate rather than interest rate, though all values may be similar. Formula 8 is also same as formula 3 at a particular point, namely $\mathrm{K}$, as shown in Figures 2 and 3.

\footnotetext{
${ }^{17}$ For further elaboration see L.L. Pasinetti, Switches of technique and the 'rate of return' in capital theory, The Economic Journal, September 1969, pp. 508531.
} 
Table 1

Farming and forestry use compared in terms of Rate of return over cost

\begin{tabular}{|c|c|c|c|}
\hline & $\begin{array}{c}\text { Net Value of } \\
\text { Farming Use }\end{array}$ & $\begin{array}{c}\text { Net Value of } \\
\text { Forestry Use }\end{array}$ & $\begin{array}{c}\text { Net Difference in Favor } \\
\text { of Forestry Use }\end{array}$ \\
\hline $1^{\text {st } y e a r ~}$ & $\$ 100$ & $\$ 0$ & $-\$ 100$ \\
\hline $2^{\text {nd }}$ year & 100 & 210 & +110 \\
\hline $3^{\text {rd }}$ year & 100 & 100 & 0 \\
\hline Each Subsequent Year & 100 & 100 & 0 \\
\hline
\end{tabular}

\section{Generalization of Two-Period Model.}

We now turn to generalization of the functions over time, and move towards social time preference analysis, which is considered to have the same pattern as that of individual. On consumption space, an assumption is taken that utility functions represented by indifference curves are convex and monotonically increasing with a diminishing rate. This assumption fulfils the macro economic requirement that consumption is a function of (disposable) income, likewise saving. As income is expected to increase over time, consumption (and saving) accordingly will also increase. Prodigality (israf) frontier however will slacken the rate of consumption in favour of saving. The consumption path thus will be steeper as depicted in Figure 8.

Figure 8

Consumption path over time

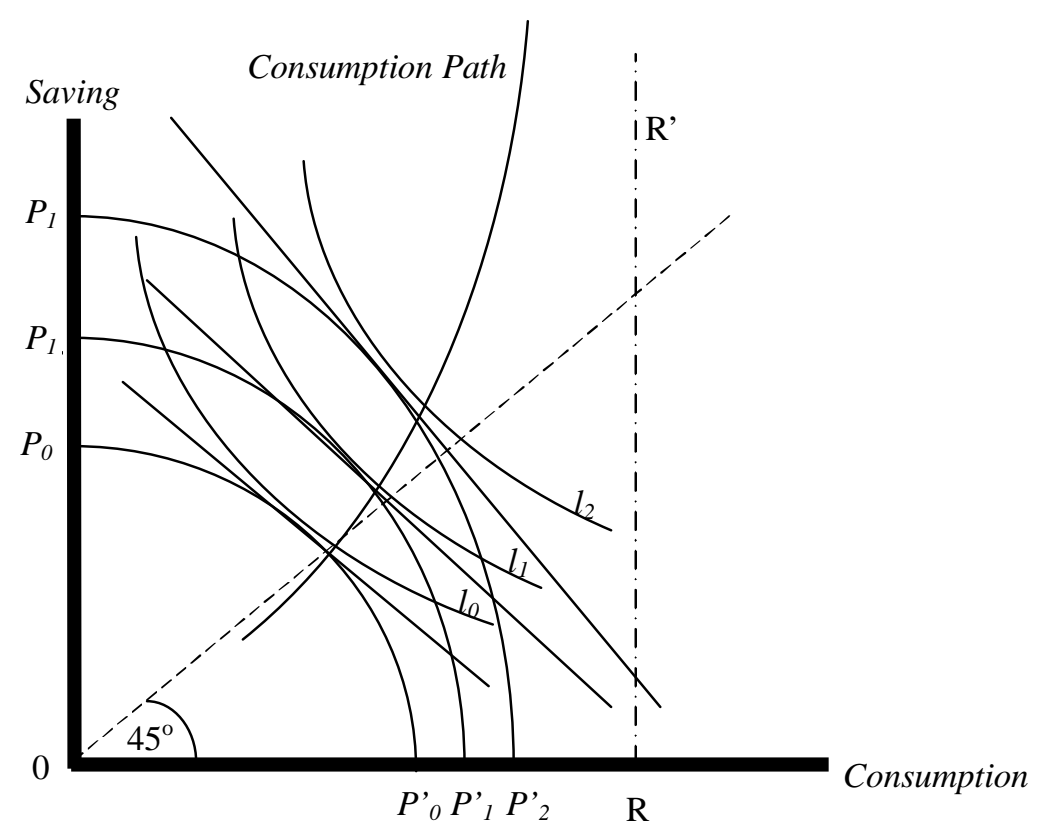

IQTISAD Journal of Islamic Economics, Vol. 4, No. 1, Muharram 1424 H/March 2003 
Figure 9

Rate of return over time

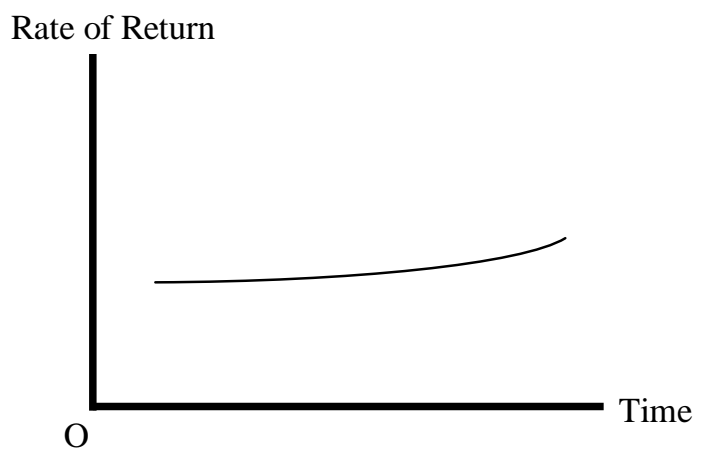

Other factors including prices being constant, it is reasonable to assume the increase in MRT over time as accumulation of reinvested capital is expected to be higher. The assumption of future consumption preference leads to high growth rate of consumption, as a result of reinvestment of saving that produces future consumption. The increase in growth rate, given the assumption of convexity properties of indifference curves, will produce an MRT (or MRTP, or in general term discount) rate (Fieldstein, 1954). However, this is subject to possible changes in population. When discussion on consumption per capita is held, prodigality frontier (RR') is still reasonable for consideration. Figure 9, derived from Figure 8 explains an increase in discount rate as a result of the increase in consumption growth rate. This conclusion differs from Azhar (1992: 233) who observes linear (constancy) rate of return (profit) over a period of time.

\section{CONCLUDING REMARKS}

Further Research Suggested

Some Muslim economists have taken the rates of return (profit) as the discount rates, to step further into developing investment decision analyses. Nevertheless, such a suggestion is meaningful from social point of view in a search for appropriate social rates of discount (SRD), of which discussion is still limited. The study concludes that, in general, social viewpoint of project evaluation concentrating on CBA necessitates more attention. Special emphases should be given to developing a new methodology in the light of the Shari'ah, but theoretically acceptable. Such a methodology should (or rather must) ensure the satisfaction of integrated equity and efficiency objectives.

In order to do so, identifying the objectives of Islamic economy is necessary condition, particularly in the operational ground, because most of the principles that have been explored by earlier efforts are similar, and thus quite sufficient. The basic principles derived from the Islamic values are unchanged, whereas the operational ground derived from the basic postulates is subject to changes in time and space.

At least two other areas appealing for further inquiries that may support some recommendations given by for instance Awan (1995) are recommended as follows:

1. Developing Islamic theories on social costs and benefits, which is possible for validation, to incorporate wider requi- 
rements in project evaluation. Such theories include exploration of social welfare function, consumer surplus and willingness-to-pay theories, pricing process, and determination of weights. This may lead to developing the Islamic methodology in project evaluation;

2. Defining the basic needs in relation to distributional weights. References to the earlier scholars' works (concerning dharuriyyat, hajjiyyat, and tahsiniyyat) as many have suggested are of great significance.

\section{Policy Prescriptions}

Having studied the subject, several policies and regulations are recommended in the study for project's analysts or assessors, policy makers and other related parties. These can be classified under six categories such as: a) investment policies and profitsharing schemes, b) banking and corporate regulations, c) zakah and taxation policies, d) schemes or other means of distribution and redistribution, e) environmental improvement policy, and lastly f) guidelines for undertaking projects. This classification is held on the basis of methodological approach developed in the study as depicted in Figure 2.1, instead of the excerpts obtained from materials under examination, notwithstanding that their policy initiatives are incorporated.

Wallahu a'lam bissawab.

\section{REFERENCES}

Akhtar, M.R. 1417/1996. "Towards an Islamic Approach for Environmental Balance." Islamic Economic Studies, 3:2, pp. 57-77

Awan, K.R. 1995. "Project Appraisal: A Comparative Survey of Selected Conventional and Islamic Economics Literature." Discussion Paper No. 13. Jeddah: IRTI/IDB
Bashir 'A.H.M. and Darrat Ali. 1992. "Equity Participation Contracts and Investment: Some Theoretical and Empirical Results. AJISS, 9, pp. 219-232

Chapra, M.U. 1979. The Islamic Welfare State and Its Role in the Economy. Leicester: Islamic Foundation

Choudhury, M.A. 1980. An Islamic Social Welfare Function. Jeddah: ICRIEKAAU

Choudhury, M.A.1983. "The Rate of Capitalization in Valuation Models in an Islamic Economics, in Fiscal Policy and Resource Allocation in Islam. Ziauddin Ahmed, Munawar Iqbal and M. Fahim Khan, eds. Jeddah: ICRIE-KAAU, pp. 287-311

Choudhury, M.A.1986. Contributions to Islamic Economic Theory: A Study in Social Economics. Hampshire: The Macmillan Press, Ltd

Choudhury, M.A.1992. The Principles of Islamic Political Economy: A Methodological Enquiry. Hampshire: St. Martin's Press

Choudhry, M A and Uzir A.M. 1992. Foundations of Islamic Political Economy. The Hampshire: Macmillan Press Ltd

Feldstein, M.S. 1964. "The Social Time Preference Discount Rate in Cost Benefit Analysis." Economic Journal. 16, pp. 360-379.

al-Jarhi, M. Ali. 1403/1982. "Comments on 'Interest Rate and Intertemporal Allocative Efficiency' by Naqvi, Syed Nawab Heidar,"in Monetary and Fiscal Economics of Islam. M. Ariff. Jeddah: ICRIE, KAAU, pp. 96-98.

Hallaq, S. 1994. "Optimum Investment Decision: an Islamic Perspective." Islamic Quarterly. 38:3, pp. 205-213

Haque, N. and A. Mirakhor. 1987. "Optimal Profit-sharing Contracts and Investment in an Interest-free Islamic 
Economy," in Theoretical Studies in Islamic Banking and Finance. Khan, Mohsin S. and Mirakhor, Abbas, eds. Houston, Texas: Institute for Research and Islamic Studies, pp.141-161

Hasan, Z.. 1986. "Distributional Equity in Islam," in Distributive Justice and Need Fulfilment in an Islamic Economy. Munawar Iqbal, ed, Islamabad: International Islamic University Islamabad, pp. 35-62.

Hirschleifer, J. 1965a. "Investment Decision under Uncertainty: A Choice-Thematic Approach." Quarterly Journal of Economics, 79, pp. 509-536.

Hirschleifer, J. 1965b. "Investment Decision under Uncertainty: Application of the State-Preference Approach." Quarterly Journal of Economics, 80, pp. 252-277.

Kahf, Monzer. 1994. "Time Value of Money and Discounting in Islamic Perspective: Revisited." Review of Islamic Economics: 3:2, pp. 31-38

Khan, M. Akram. 1985. "Resource Allocation in an Islamic Economy. Islamic Quarterly, 29, pp. 240-250.

Khan, M. Akram. 1997. "The Role of Government in the Economy." AJISS, 14:2 (Summer), pp. 155-171

Khan, M. Fahim. 1991. "Time Value of Money and Discounting in Islamic Perspective." Review of Islamic Economics? Majallat Buhuth alIqtisadi al-Islami, 1:2, pp. 35-45

Khan, M. Fahim. 1995. Essays in Islamic Economics. Leicester: The Islamic Foundation

Little, I.M.D. and J.A Mirrlees. 1969. Manual of Industrial Project Analysis in Developing Countries: Methodology and Case Studies, vol. 2. Paris: OECD.

Little, I.M.D. and J.A. Mirrlees. 1974. "Project Appraisal and Planning for Developing Countries. London: Heinemann.

Mannan, M. Abdul. 1413/1993. Understanding Islamic Finance: A Study of the Securities Market in an Islamic Framework. Jeddah: IDB/IRTI.

Mannan, M.A. 1992. “Allocative Efficiency, Decision and Welfare Criteria in an Interest-free Islamic Economy: A Comparative Policy Approach," in Readings in Microeconomics: an Islamic Perspective. Sayyid Tahir, Aidit Ghazali, and Syed Omar Syed Agil.. Petaling Jaya: Longman Malaysia, pp. 220-238

Marglin, S.A. 1963a. "The Social Rate of Discount and Optimal Rate of Investment." Quarterly Journal of Economics, 77(Feb), pp 95-111.

Marglin, S.A. 1963b. "The Opportunity Cost of Public Investment." Quarterly Journal of Economics, 77(May), pp. 274-289.

Mirakhor, A.. 1996. "Cost of Capital and Investment in a Non-interest Economy." Islamic Economic Studies, 4:1, pp 35-46

Mishan, E.J. 1982. Cost-Benefit Analysis. $3^{\text {rd }}$ ed. London: George Allen \& Unwin.

Naqvi, S.N.H. 1401/1981a. Ethics and Economics: An Islamic Synthesis. Leicester: The Islamic Foundation

Naqvi, S.N.H. 1981b. On Replacing the Institution of Interest in a Dynamic Economics Islamic Economy. Islamabad: Pakistan Institute of Development Economics

Naqvi, S.N.H. 1403/1982. "Interest Rate and Inter-temporal Allocative Efficiency in an Islamic Economy," in Monetary and Fiscal Economics of Islam. M. Ariff. Jeddah: ICRIE-KAAU, pp. 75-95 
Naqvi, S.N.H. 1994. Islam, Economics, and Society. London: Kegan Paul International

Naqvi, S.N.H., Beg, H.U., Rafiq Ahmed and Nazeer, Mian M. 1989. An Agenda for Islamic Economic Reform. Islamabad: Pakistan Institute of Development Economics.

Naqvi-Qadir 1981 Naqvi, S.N.H and Asghar Qadir. 1981. A Model of a Dynamic Economy and the Institution of Interest. Islamabad: Pakistan Institute of Development Economics

Pearce, D.W. 1983. Cost-Benefit Analysis, $2^{\text {nd }}$ ed. London: The MacMillan Press Ltd.

Pohl, G. and Mihaljek. D. 1992. "Project Evaluation and Uncertainty in Practice: A Statistical Analysis of Rateof-Return Divergences of 1,015 World Bank Projects." World Bank Economic Review. 6:2(May), pp. 255-277.

Rauf A. 1412/1992. "A Theory of Optimal Investment Decision in an Islamic Economy," in Lectures In Islamic Economics. Ausaf Ahmad and K.R. Awan, eds. Jeddah: IRTI/IDB, pp. 217-242

Sattar, Zaidi. 1991. "A Dynamic Investment Model with Profit-sharing an an Interest-free Economy: Methodological Issues. AJISS, 8, pp 109-124

Shafey, Irfan. 1986. "Comments on 'Distributional equity in Islam' by Zubair Hasan,"in Distributive Justice and Need Fulfillment in an Islamic Economy. Munawar Iqbal, ed. Islamabad: International Islamic University, pp. 63-84

UNIDO and IDCAS. 1980. Manual for Evaluation of Industrial Projects. New York: United Nations Publication.

Zaman, Asad. 1992. "Towards Foundations for an Islamic Theory of Consumer
Behaviour," in Readings in Microeconomics. Sayyed Tahir, Aidit Ghazali and Syed Omar Syed Tahir, eds. Petaling Jaya: Longman Malaysia, pp. 81-89

Zarqa', M.A. 1976. "Islamic Economics: An Approach to Human Welfare," in Studies in Islamic Economics. K. Ahmad, ed. Leicester: Islamic Foundation, pp.3-18

Zarqa', M.A. 1403/1982. "Comments on 'Interest Rate and Intertemporal Allocative Efficiency' by S.N.H. Naqvi," in Monetary and fiscal economics of Islam. Mohammad Ariff. Jeddah: ICRIE, KAAU, pp. 98-106

Zarqa', M.A. 1983. “An Islamic Perspective on the Economics of Discounting in Project Evaluation," in Fiscal Policy and Resource Allocation in Islam. Ziauddin Ahmed, Munawar Iqbal and M. Fahim Khan, eds. Jeddah: ICRIE-KAAU, pp. 203-234

Zarqa', M. Anas. 1992. "A Partial Relationship in a Muslim's Utility Function," in Readings in Microeconomics. Sayyed Tahir, Aidit Ghazali and Syed Omar Syed Tahir, eds. Petaling Jaya: Longman Malaysia, pp. 105-112.

Zarqa', M A. 1415/1994. "Financing and Investment in Awqaf Projects: A Non-technical Introduction." Islamic Economics Studies. 2:1, pp. 55-62 

